\title{
SEMIÓTICA DA MARCA DOS PRODUTOS PROCTER \& GAMBLE NO FILME "MINHA MÃE É UMA PEÇA"
}

\author{
Semiotics of brand of Procter \& Gamble products in the movie "Minha Mãe é \\ uma peça"
}

\section{Semiótica de la marca de los productos de Procter \& Gamble en la película "Minha Mãe é uma peça"}

Pablo Moreno Fernandes Viana ${ }^{1}$

\begin{abstract}
Resumo
Este artigo analisa a estratégia de publicidade-entretenimento de integração de produtos em filmes (DONATON, 2007), que se destacam em "Minha Mãe é uma peça”, filme nacional mais assistido nos cinemas brasileiros em 2013, usando como instrumento de análise semiótica de Peirce. O cinema brasileiro passa, desde os últimos 20 anos, por um período de crescimento, chegando em 2000 Com uma presença significativa na cultura nacional. Ano após ano, os filmes brasileiros se destacam entre os mais assistidos no país. Isso tem contribuído para a organização do cinema como indústria, como no caso de filmes produzidos pela Globo Filmes, por exemplo. Com uma indústria cinematográfica em formação, tem sido cada vez mais frequente integração de produtos, marcas e publicidade no conteúdo dos filmes nacionais. $\mathrm{O}$ estudo analisa a estratégia de integrações de produtos da Procter \& Gamble na história. Pretende-se verificar a contribuição dessa estratégia como elemento de expressividade da marca (PEREZ, 2004), na construção de valores simbólicos para os consumidores.
\end{abstract}

Palavras-chave: publicidade-entretenimento, semiótica da marca, cinema.

\begin{abstract}
${ }^{1}$ Doutorando em Ciências da Comunicação pela ECA-USP, Mestre em Comunicação: Interações Midiáticas pela PUC Minas (2009), Especialista em Imagens e Culturas Midiáticas pela UFMG (2006), Graduado em Comunicação Social: Publicidade e Propaganda pelo Centro Universitário Newton Paiva (2005). Atualmente é professor assistente IV da PUC Minas, lecionando no Campus Poços de Caldas as disciplinas "Introdução à Publicidade", "Cinema e Vídeo" e "Direção de Arte". E-mail: pablomoreno@gmail.com
\end{abstract}


Semiótica da marca dos produtos Procter \& Gamble no filme "minha mãe é uma peça"

de Pablo Moreno Fernandes Viana

This paper analyzes the advertisement strategy of branded content (DONATON, 2007) that stand out in "Minha Mãe é uma peça", most watched domestic brazilian film in 2013, using as analytical instrument the Peirce's semiotics. Brazilian cinema passes, since the last 20 years, for a period of growth, arriving in 2000's with a significant presence in the national culture. Year after year, Brazilian films stand out among the most watched in the country. That has contributed to the organization of cinema as industry, as in the case of movies made by Globo Filmes, for example. With a Brazilian film industry in formation, has been increasingly frequent integration of products, brands and advertising in the content of national films. The study analyzes the Branded Content strategy of Procter \& Gamble products in the story. It is intended to verify the contribution of this strategy in expressivity of brand (PEREZ, 2004), in the construction of symbolic values to consumers.

Keywords: advertisement, semiotics of brand, cinema.

\section{Resumen}

Este artículo analiza los productos de publicidad-entretenimiento integrados en películas (DONATON, 2007), que se destacan en "Minha Mãe é uma peça" más vistos película nacional en los cines brasileños en 2013, utilizando como herramienta de análisis semiótico Peirce. Cine brasileño pasa, ya que los últimos 20 años, por un período de crecimiento, llegando en el año 2000 con una presencia significativa en la cultura nacional. Año tras año, las películas brasileñas destacan entre los más vistos en el país. Esto ha contribuido a la organización del cine como industria, como en el caso de las películas producidas por Globo Filmes, por ejemplo. Con una industria cinematográfica en formación, ha sido cada vez más frecuente la integración de productos, marcas y publicidad en el contenido de las películas nacionales. Examina la estrategia de integración de los productos de Procter \& Gamble en la historia. El objetivo es verificar la contribución de esta estrategia como elemento expresivo de la marca (PEREZ, 2004), en la construcción de valores simbólicos a los consumidores.

Palabras-clave: publicidad-entretenimiento, semiótica de la marca, cinema.

O cinema norte-americano caracteriza-se por seu aspecto industrial e uma ampla cadeia produtiva está inserida em sua lógica. A publicidade faz parte dessa cadeia e é cada vez mais raro, senão improvável, haver um filme norte-americano sem 
Semiótica da marca dos produtos Procter \& Gamble no filme "minha mãe é uma peça"

integração de produtos e marcas em suas narrativas. Essas ações representam grandes investimentos, visto que é comum os consumidores reagirem melhor às mensagens publicitárias quando estas são inseridas em conteúdos de entretenimento.

O cinema brasileiro passa, desde meados dos anos 90, por um período de recuperação e crescimento, chegando nos anos 2000 com significativa representatividade nas salas. Ano a ano, filmes brasileiros se destacam entre os mais assistidos do país e caem no gosto da população. Isso tem contribuído para a organização de um cinema enquanto indústria, como no caso das obras realizadas pela Globo Filmes, por exemplo.

Com uma indústria cinematográfica brasileira em formação, tem sido cada vez mais frequente a integração de produtos, marcas e mensagens publicitárias no conteúdo dos filmes nacionais. Um exemplo é "Minha Mãe é uma peça", filme nacional mais assistido no Brasil em 2013. A obra teve público de 4,6 milhões de espectadores, segundo a Agência Nacional do Cinema (Ancine).

Este trabalho propõe-se a analisar as integrações de produtos (DONATON, 2007) que mais se destacam em "Minha Mãe é uma peça", utilizando como instrumento de análise a semiótica peirceana. Pretende-se verificar a contribuição dessa estratégia como um dos espectros de expressividade da marca (PEREZ, 2004), na construção de valores simbólicos para os consumidores.

"Minha Mãe é uma peça" tem como patrocinadores as marcas Eletrobras, Procter \& Gamble e Grupo Protege. Na categoria de apoios surgem as marcas BB DTVM, TAESA, Multishow, Quanta Estúdios, Teleimage e Finep. De todas as marcas patrocinadoras/apoiadoras do filme, a que mais se destaca é a Procter \& Gamble, por meio de três produtos de seu portifólio: o sabão líquido para lavar roupas Ariel, o shampoo Pantene e o amaciante de roupas Downy. Os produtos são inseridos na narrativa em quatro momentos, seus nomes são mencionados por personagens e suas marcas são exibidas por longo período de tempo em primeiro plano.

Diante da maior recorrência, portanto, recorta-se como objeto empírico de análise as inserções dos produtos Procter \& Gamble (P\&G). A pesquisa analisa, a partir da semiótica da marca, os signos construídos para os produtos sob o aspecto do signo em si mesmo, do signo em relação ao objeto e do signo em relação ao interpretante (SANTAELLA, 2002) na narrativa de entretenimento. A intenção é verificar os valores construídos e, posteriormente, compará-los ao posicionamento 
Semiótica da marca dos produtos Procter \& Gamble no filme "minha mãe é uma peça"

de Pablo Moreno Fernandes Viana

institucional, checando se as inserções realizadas são condizentes com a expressividade da marca. Além disso, pretende-se ainda verificar a forma como a mensagem é apresentada enquanto entretenimento e o tipo de raciocínio que convoca do espectador, ainda de acordo com a semiótica peirceana: abdução, dedução ou indução.

\section{ENTRETENIMENTO COMO LUGAR DE EXPRESSIVIDADE DA MARCA}

$\mathrm{Na}$ contemporaneidade, as formas de consumo caracterizam-se pela velocidade "A publicidade é algo inerente às sociedades que operam em modelos econômicos de produção intensiva. (...) Nesse contexto, é resultante dos mesmos processos que foram estruturados pelos mercados ao longo dos séculos, e hoje constitui uma etapa essencial na composição do modelo de produção das organizações modernas." (SANTOS, 2005: 24). Assim, o volume de produtos e marcas em oferta na contemporaneidade cresceu, sendo necessário escoar a produção mais rapidamente.

Se muda a forma de consumir, mudam também os argumentos da mensagem publicitária. Eles sofisticam-se e ela deixa de ser um mero instrumento de interrupção da experiência dos sujeitos com os meios de comunicação de massa. Ela passa a disputar a atenção do espectador, aproximando-se cada vez mais de um discurso do entretenimento.

Luhmann (2005), ao definir os meios de comunicação, reconhece a função pouco nobre da publicidade nesses espaços. Segundo o autor, "O espaço da programação atribuído às notícias e reportagens é o que mais facilmente se reconhece como sendo de elaboração e processamento de informações" (LUHMANN, 2005: 83). Essa afirmação do autor demonstra o papel atribuído até então à mensagem publicitária dentro dos meios de comunicação: ela interrompia a experiência dos consumidores e não era reconhecida como um trabalho de elaboração e processamento de informações, apesar de sua função primordial de geração de receitas para os veículos.

Tal perspectiva transforma-se a partir das associações entre publicidade e entretenimento e um aumento dessa estratégia enunciativa. Esse novo formato não oculta suas intenções enquanto mensagem publicitária. No entanto, insere dentro de 
Semiótica da marca dos produtos Procter \& Gamble no filme "minha mãe é uma peça"

sua mensagem recursos presentes em produtos comunicacionais do entretenimento, visando ampliar a atenção do público para o que é veiculado. "Cada vez mais as mensagens publicitárias ocupam-se em tornar desconhecido ao destinatário o motivo daquilo que é anunciado. Ele reconhece que se trata de publicidade, mas não que está sendo influenciado" (LUHMAN, 2005: 84). Essa forma de anunciar, combinando elementos publicitários com conteúdos de entretenimento é conhecida como Advertainment, Publicidade-entretenimento, entre outros nomes.

Luhmann (2005), afirma que "o entretenimento busca, principalmente pelo fato de ser oferecido de fora, ativação daquilo que é vivido, esperado, temido, esquecido por si mesmo - como faziam, no passado, os mitos que eram relatados (LUHMANN, 2005: 103)". Por esse motivo, a publicidade-entretenimento gera mais lembrança que a propaganda tradicional. Essa nova mensagem publicitária, mais sofisticada, que apresenta-se como produto de entretenimento, diferencia-se porque o espectador quer assisti-la, ao contrário da publicidade tradicional, que interrompia a experiência dos sujeitos, invadindo a programação com as ofertas de produtos e serviços. Essa nova publicidade apresenta-se como entretenimento midiático, à disposição para ser consumida pelo espectador, enquanto oferece conteúdos publicitários.

Donaton (2007) traça um panorama das revoluções tecnológicas e das transformações nos hábitos de consumo da sociedade norte-americana que levaram os sujeitos a uma nova lógica, na qual o espectador ganha hegemonia como elemento decisório no processo de consumo midiático e que demanda novas formas de contato da propaganda com o consumidor. Sobre isso, Netto, afirma que "da função de oferta de produto da publicidade tradicional à troca de diversão por imagem positiva em relação à marca, temos uma alteração relevante no viés comunicativo estabelecido na relação do indivíduo com a publicidade (NETTO, 2008: 7).

Essa forma de anunciar foge dos espaços tradicionais em que essa mensagem se inseria anteriormente. "Em termos temporais, a internet oferece uma versão híbrida das mídias impressas e eletrônicas, já que permite ao consumidor definir quanto tempo ficará em contato com a marca ou qual será seu caminho através do site" (NETTO, 2008,: 18). A publicidade deixa os espaços reservados para os anúncios de revista, sai dos intervalos comerciais e encontra, novos espaços para ser consumida a 
Semiótica da marca dos produtos Procter \& Gamble no filme "minha mãe é uma peça"

qualquer momento, por quanto tempo e quantas vezes o espectador julgar necessário, sendo chamada de publicidade-entretenimento.

A publicidade-entretenimento é classificada por Donaton (2007) em cinco categorias: Publicidade de longo formato, Inserção de mensagens publicitárias (branded content), Integração de produtos em filmes, Parcerias com a indústria da música, Programas financiados por anunciantes.

Este trabalho debruça-se, especificamente, sobre a categoria Integração de produtos em filmes, muito popular nos Estados Unidos, visto que eles são um dos poucos países no mundo que tem no cinema uma indústria consolidada. $\mathrm{O}$ autor explica que "A inserção de produtos em filmes é uma prática corrente desde os primórdios do cinema, porém as parcerias entre ficção cinematográfica e produtos se tornaram nos dias de hoje significativamente mais profundas. Aos publicitários é dada voz ativa no desenvolvimento do roteiro muito antes do início das filmagens.” (DONATON, 2007: 32).

Integrar produtos em filmes é algo feito com maestria no cinema norteamericano. Os Estados Unidos possuem a peculiaridade de terem transformado seu cinema numa indústria pouco depois da consolidação do cinema como forma expressiva, o que faz dos filmes norte-americanos um produto comercial, rentável e que vise lucro.

\begin{abstract}
A inserção de produtos nos filmes é uma prática corrente desde os primórdios do cinema, porém as parcerias entre ficção cinematográfica e produtos se tornaram nos dias de hoje significamente mais profundas. Aos publicitários é dada voz ativa no desenvolvimento do roteiro muito antes do início das filmagens. (DONATON, 2007: 33)
\end{abstract}

A exibição de marcas em filmes norte-americanos é corriqueira. Há casos memoráveis como Bonequinha de Luxo (1961), que trazia uma importante marca em seu título original (Breakfast at Tiffany's), ilustrando como a presença das marcas e o universo simbólico trazido por elas faz-se presente na cultura norte-americana como um todo. A marca já estava presente no título original do livro que deu origem ao filme, com a diferença que, na narrativa audiovisual, a loja física fez-se presente na história, representando o espaço, os produtos e a experiência de consumo construída pela personagem, com base nos valores da marca. 
Semiótica da marca dos produtos Procter \& Gamble no filme "minha mãe é uma peça"

De tão frequentes, as inserções publicitárias no cinema sofisticaram-se com o tempo. Isso despertou a curiosidade de pesquisadores, que debruçaram-se sobre o tema para investigá-las e classificá-las. Cabe destacar que o formato que se deseja investigar nesse trabalho corresponde à integração de produtos em filmes no sentido de que os filmes são, de fato, inseridos na narrativa, e não sobre os anúncios publicitários exibidos nas salas de cinema antes dos filmes.

Essas ações de integração de produtos em narrativas audiovisuais são frequentemente conhecidas, também, como Product Placement. O formato recebe muitas críticas por ser utilizado de forma descontextualizada ou por interromper a experiência dos espectadores, atuando de forma pouco sutil, descortinando a presença da publicidade. "Muito embora detentor de excelentes oportunidades de contato com o público-alvo de qualquer produto ou serviço, o product placement é utilizado em inúmeras ocasiões de maneira frágil ou descontextualizado" (CHACEL, BRONSZTEIN, 2010: 113). Os autores destacam, portanto, o grande benefício dessa ação, que é a possibilidade de contato com o público, mas rechaçam a ideia de que esse contato seja feito de maneira antinatural dentro da narrativa.

Chacel e Bronsztein (2010) citam Palácios (2010) para caracterizarem uma forma de product placement mais contextualizada à narrativa, chamada de story placement. Segundo os autores, esse formato,

além de integrar conteúdo publicitário e narrativa, produto, serviço, marca ou empresa passam a fazer parte da trama de maneira tão contextualizada que sua ausência compromete o desenrolar eficaz da narrativa. Com efeito, a estratégia de story placement funciona tomando como base o mundo narrado (diegético), e a partir dele o produto, o serviço, a marca ou a empresa podem ser inseridos na narrativa de modo verossímil, verdadeiro, único e totalmente desinteressado. (CHACEL, BRONSZTEIN, 2010: 113)

O conceito de Story Placement explica a Integração de produtos em filmes como se pretende analisar nesse trabalho. Além do filme Bonequinha de Luxo, outro exemplo destacado é o filme Náufrago (2001), que traz diversas inserções da marca FedEx, além de outros exemplos que podem ser mencionados, como a franquia Transformers, O Diabo Veste Prada, Sex and The City, entre outros. Sêga (2012), também discute essa interdependência estabelecida entre cinema e publicidade e reforça: "Vários filmes produzidos na primeira década do século XXI, criaram uma 
Semiótica da marca dos produtos Procter \& Gamble no filme "minha mãe é uma peça"

relação de interdependência entre cinema e publicidade, estimulando o telespectador a consumir marcas que interagem com os personagens" (SÊGA, 2012: 48).

O pensamento dos autores, comprova, portanto, o status da integração de produtos em filmes no cinema americano. Publicidade e Entretenimento associaramse, visando benefícios para os dois formatos, ao passo que a publicidade beneficia-se da oportunidade de dialogar com o consumidor em um novo estatuto, enquanto o cinema recebe as verbas publicitárias dos anunciantes.

\section{E NO CINEMA BRASILEIRO?}

Ao longo da história, percebe-se que o cinema brasileiro sempre teve uma produção antenada aos períodos mais importantes do cinema mundial. No entanto, o cinema do país sempre esteve sujeito a intempéries por conta de problemas econômicos, políticos e sociais.

O cinema nacional passou por uma fase regional e experimental com Humberto Mauro, passou por tentativas de industrialização, entre os anos 1930 e 1950, escancarou os problemas sociais na busca por uma identidade própria com o Cinema Novo, enfrentou a censura da ditadura militar e a falta de recursos com o cinema marginal e as pornochanchadas, mas teve sua morte praticamente decretada nos anos 1980 com os malfadados planos econômicos da época, entre outros fatores.

Os anos 1990 sinalizaram para um renascimento, em um período batizado de retomada, justamente pelo retorno de políticas de investimento no cinema, incentivo ao audiovisual e a criação da Ancine, órgão regulamentador do cinema nacional. Cabe destacar que o cinema brasileiro buscou reestruturar-se sem políticas protecionistas, lutando sob as regras de mercado, com o cinema norte-americano. Os anos 1990 foram muito produtivos para o cinema nacional. Vários filmes foram indicados e receberam prêmios internacionais diversos, uma indústria cinematográfica, adequada à proporção do cinema brasileiro começou a estruturar-se e, principalmente, o público passou a interessar-se pelos filmes, vencendo preconceitos consolidados sobre as produções feitas no país.

Com esse amadurecimento, percebeu-se que a cada ano que passava, mais e mais filmes brasileiros tornavam-se sucessos de bilheteria e eram buscados pelo público. O interesse da audiência atrai anunciantes, que investem nos filmes e querem 
Semiótica da marca dos produtos Procter \& Gamble no filme "minha mãe é uma peça"

inserir suas marcas nas histórias. Isso fez nascer, também, a integração de produtos em filmes nacionais, como se analisa a seguir.

\section{MINHA MÃE É UMA PEÇA (2013)}

"Minha Mãe é uma peça" foi o filme nacional mais assistido nos cinemas brasileiros em 2013. Segundo relatório da Ancine, o filme foi assistido por 4.600.145 espectadores. O filme, do gênero comédia, é uma adaptação de uma peça teatral para o cinema e conta com uma série de patrocínios e apoios, que são apresentados nos créditos iniciais. Dentre os patrocínios aparecem a Eletrobras, a Procter \& Gamble e o Grupo Protege. Na categoria de apoios surgem as marcas BB DTVM (Divisão do Banco do Brasil que administra títulos e valores imobiliários, TAESA (Empresa privada do segmento de transmissão de energia), o canal de TV Multishow, o estúdio Quanta, a produtora Teleimage, a Finep.

O filme é uma realização da Telecine Filmes e sua marca aparece nos créditos iniciais, antes dos patrocínios e apoios. A marca do canal de TV Telecine aparece, no momento em que Dona Hermínia assiste um filme na televisão e o logotipo da emissora é exibido no canto superior direito da tela da televisão.

Outra marca que aparece com bastante destaque é a Peugeot, embora não conste entre os patrocinadores do filme e não sejam feitas menções da marca pelos personagens. Carlos Alberto, ex-marido de Dona Hermínia dirige um Peugeot 308 vermelho conversível e o carro aparece várias vezes ao longo do filme, num deles, quando é filmado de frente, com a marca em destaque por alguns segundos.

De todas as marcas patrocinadoras/apoiadoras, a única que se insere de forma marcante na narrativa de "Minha Mãe é uma peça" é a Procter \& Gamble, que tem três de suas marcas presentes em dois momentos distintos da narrativa. Ao todo, três marcas da P\&G são exibidas: Ariel, Pantene e Downy.

\section{EXPRESSIVIDADE DA MARCA}

As informações disponíveis sobre o posicionamento da marca no site da $P \& G$ ou no site próprio da marca deram base para a análise realizada para as inserções presentes em "Minha Mãe é uma peça”. A organização utiliza uma estratégia de 
Semiótica da marca dos produtos Procter \& Gamble no filme "minha mãe é uma peça"

de Pablo Moreno Fernandes Viana

gestão de seus produtos corporativas que utiliza marcas individuais. Segundo Perez, essa estratégia tem como vantagens:

flexibilidade e menor rigidez na escolha do nome que melhor se adapte às características, aos atributos, ao público receptor, ao contexto, à época elou ao posicionamento do produto. (...) Possibilita maior ocupação de espaço nos pontosde-venda. Maior otimização da segmentação de mercado. Proporciona a sensação de inovação e modernidade para o consumidor. (PEREZ, 2004: 20-21).

Tal estratégia é utilizada pela Procter \& Gamble em seus produtos. Cada um dos produtos possui uma marca individual, uma estratégia de comunicação independente e a marca principal, em alguns casos, chega a ser desconhecida pelo consumidor. Os produtos Procter \& Gamble integram um extenso portfolio de produtos de cuidado pessoal. De acordo com o site da organização, seu propósito é:

Oferecer produtos e serviços de qualidade superior, que melhorem a vida de consumidores no mundo todo, agora e para as gerações futuras. Como resultado, os consumidores vão nos recompensar com a liderança de mercado, lucros e criação de valor, permitindo que nossa gente, nossos acionistas e as comunidades onde vivemos e trabalhamos prosperem. (PROCTER \& GAMBLE, 2014)

Os valores defendidos pela organização são "Integridade, Liderança, Propriedade, Paixão por vencer, Confiança" (PROCTER \& GAMBLE, 2014). Os princípio expostos no site são:

Mostramos respeito por todos os indivíduos; Os interesses da companhia e do indivíduo são inseparáveis; Temos foco estratégico em nosso trabalho; Nosso sucesso é baseado em Inovação; Valorizamos a competência pessoal; Ambicionamos ser os melhores; Temos foco externo; A interdependência mútua é um estilo de vida. (PROCTER \& GAMBLE, 2014)

No site oficial da $\mathrm{P} \& \mathrm{G}$ é possível obter informações sobre os produtos ou ser direcionado para os sites oficiais das marcas (quando disponíveis). No caso das marcas inseridas em "Minha Mãe é uma peça", somente Downy não possui um site oficial.

O texto de apresentação da marca Ariel, no site oficial da $P \& G$, afirma que:

No final dos anos 60, Ariel foi lançado no mundo todo. Foi um momento em que as pessoas acreditavam que poderiam fazer uma diferença enorme no mundo, um momento de desafios e de idealismos, de visão transformada em ação. Para Ariel, tratava-se de imaginação, determinação e empoderamento tecnológico libertando as mulheres do seu tradicional papel doméstico. (PROCTER \& GAMBLE, 2014) 
Semiótica da marca dos produtos Procter \& Gamble no filme "minha mãe é uma peça"

de Pablo Moreno Fernandes Viana

No site oficial dos produtos Ariel não há informações complementares sobre o posicionamento da marca (Missão, Visão e Valores). Há apenas descrição dos produtos, um vídeo publicitário da campanha atual, dicas de uso dos produtos e uma área reservada para contato.

Sobre a marca Pantene, o texto de apresentação no site oficial da P\&G afirma que:

Há mais de 60 anos, Pantene tem oferecido aos consumidores qualidade insuperável em produtos de alta tecnologia que têm refletido uma abordagem séria e efetiva para proporcionar cabelos bonitos e saudáveis. (...)Hoje no Brasil Pantene conta com 8 linhas de produtos diferentes com Shampoo e Condicionador, além de uma linha completa de tratamentos que oferece proteção e restauração aos fios. Sua fórmula exclusiva de pró-vitaminas age como um verdadeiro escudo protetor contra danos, ao mesmo tempo que repara os fios profundamente por meio de uma tecnologia avançada que atua onde o fio mais necessita, mantendo os cabelos bonitos $e$ saudáveis. (PROCTER \& GAMBLE, 2014)

O site oficial, assim como no caso dos produtos Ariel não apresenta informações complementares sobre o posicionamento de marca, como Missão, Visão e Valores. Mas é mais completo e oferece serviços de consulta especializada sobre cabelos, apresenta os produtos, penteados, fala sobre o Pantene Institute e conta a história da marca desde sua origem até sua chegada ao Brasil. Destaca-se o trecho que apresenta a modelo Gisele Bündchen como embaixadora da marca, em 2007. A partir daí, a modelo brasileira passa a ilustrar todas as imagens da linha do tempo da marca.

A marca mais TOP se une à maior TOP do Brasil e do mundo: Em 2007, para o relançamento de Pantene no Brasil com novas fórmulas e embalagens, a marca contrata a über model Gisele Bündchen como embaixadora oficial. Desde então, a parceria de sucesso se torna cada vez mais sólida e Pantene é sinônimo de performance superior e a aliada de Gisele para cuidar da saúde das madeixas mais lindas e inspiradoras do país. (PROCTER \& GAMBLE, 2014)

Das três marcas presentes em "Minha Mãe é uma peça", Downy é a única que não possui um site próprio. As únicas informações disponíveis sobre a marca estão no próprio site da $\mathrm{P} \& \mathrm{G}$.

Downy acredita que as emoções ganham vida através do toque dos tecidos. São simples momentos, como quando você veste uma roupa limpinha e perfumada e se sente linda, pronta para enfrentar o dia. 
Semiótica da marca dos produtos Procter \& Gamble no filme "minha mãe é uma peça"

de Pablo Moreno Fernandes Viana

Ou, quando você volta, e se envolve no frescor dos seus lençóis para uma noite de sono.

É nesses momentos que Downy faz toda a diferença. Porque quando você usa Downy em seus tecidos, eles se tornam mais que tecidos, eles se tornam experiências mais significativas. Com o perfume de Downy, você reaviva suas emoções.

Como pode-se perceber, cada uma das marcas apresenta-se de forma específica para o público e visa ser reconhecida de acordo com o perfil de consumo daqueles que adquirem o produto. A forma como cada uma dessas marcas comunicase com seu público é o que Perez conceitua como expressividade da marca. A autora afirma que:

As marcas se expressam, se dão a ver, se mostram de diversas maneiras, com o objetivo de potencializar seus efeitos de sentido. (...) $O$ objetivo é estabelecer uma conexão - e se esta for emocional, tanto melhor. (...) As marcas se expressam por meio do nome que apresentam, do logotipo, da forma e do design dos produtos que encarnam, da embalagem e do rótulo, da cor, do slogan, do jingle, da personalidade, do personagem que representa, de um mascote, além de outros recursos e do contexto organizacional, envolvendo os funcionários e os parceiros e suas relações com o meio social. (PEREZ, 2004: 47)

Assim, em qualquer situação que a marca esteja em contato com consumidores (e potenciais consumidores), ela está construindo sentido, uma percepção. Perez prossegue, “o espaço perceptual da marca pode ser utilizado como um espelho que reflete o estilo de vida e os valores do consumo atual ou potencial (PEREZ, 2004: 48). A identidade institucional, a publicidade, a promoção de vendas, os patrocínios, a comunicação interna, entre outros, são momentos de expressividade de marca. Essa é uma das justificativas para que as marcas patrocinem filmes, realizando inserções de seus produtos, num contexto de entretenimento, estabelecendo contato com o consumidor num contexto de comunicação diverso ao da publicidade.

\section{DA SEMIÓTICA À SEMIÓTICA DA MARCA}

A Semiótica divide-se em uma série de correntes e, para efeitos metodológicos, é importante delimitar que a análise a ser feita nesse trabalho adota a perspectiva peirceana. Concebida por Charles S. Peirce como uma "teoria dos signos e da representação que efetua uma extensão da lógica para o limite da cognição e da experiência dos fenômenos" (PINTO, 1995: 10), a Semiótica pode ser aplicada para a 
Semiótica da marca dos produtos Procter \& Gamble no filme "minha mãe é uma peça"

análise de manifestações diversas, como da publicidade, por exemplo. Da ampla produção de Peirce em torno da Semiótica, o trabalho dedica-se, primeiramente, à gramática especulativa (SANTAELLA, 2002), a partir das dez categorias do signo classificadas por Peirce para compreendermos a publicidade-entretenimento. Outra vertente dos estudos de Peirce estava na lógica crítica, "que estuda os tipos de argumentos - abdutivos, indutivos e dedutivos" (SANTAELLA, 2002: 47), que será utilizada para a compreensão do processo de produção de sentido nas mensagens a serem analisadas.

A partir da Teoria Geral dos signos e o processo de semiose que parte da relação entre signo, objeto e interpretante, foi concebida a semiótica da expressividade marcária.

Nesse modelo, O objeto reside no "Marketing Mix, no produto, na sua concretude e nos seus aspectos de distribuição, preço, design, entre outros" (PEREZ, 2004: 152). No entanto, o objeto não deve ser considerado algo simplesmente material, podendo ser também simplesmente uma posição lógica na tríade, um objeto dinâmico. Assim, a autora prossegue explicando que o objeto não se limita ao produto: "leva em conta toda a complexidade da organização, sua missão, visão e valores, suas relações com a sociedade e seus dirigentes, ampliando a referencialidade imediata reduzida ao produto tangível” (PEREZ, 2004: 152).

O signo é compreendido como os "elementos que dão expressividade e visibilidade à marca" (PEREZ, 2004: 153), o que Lencastre citado por Perez (2004) conceitua como Identity Mix.

O interpretante vai corresponder aos efeitos gerados pelo signo, no processo de produção de sentido. Tais efeitos, segundo Perez, podem ser emocionais/afetivos (de primeiridade), enérgicos quando representam funcionalidade (de secundidade) e lógicos (de terceiridade) quando correspondem a hábitos.

Partindo desse modelo, inicia-se, portanto, da manifestação do signo nele mesmo, ou seja, do Identity Mix. A marca surge como patrocinadora do filme e solicita aos roteiristas que concebessem situações nas quais os produtos fossem inseridos dentro da narrativa, com capacidade expressiva. De acordo com Perez, “neste primeiro nível analítico, o signo é pura possibilidade qualitativa. É observado nas suas propriedade internas, quer dizer, nos seus aspectos qualitativos, sensórios (...) etc" (PEREZ, 2004: 155) 
Semiótica da marca dos produtos Procter \& Gamble no filme "minha mãe é uma peça"

de Pablo Moreno Fernandes Viana

Peirce classifica essa primeira divisão do signo em três divisões: qualissignos, sinsignos e legissignos. "Um Qualissigno é uma qualidade do que é signo" (CP 2.244); "Um sinsigno é uma coisa ou evento existente e real que é um signo" (CP 2.245); "Um Legissigno é uma lei que é um Signo. (...) Todo legissigno significa através de um caso de sua aplicação, que pode ser denominada Réplica. (...) A réplica é um sinsigno. Assim, todo Legissigno requer Sinsignos" (CP 2.246). As três divisões serão úteis para a compreensão dos signos representados.

Dando sequência à interpretação, verifica-se "as mensagens em relação ao objeto que estão representando" (PEREZ, 2004: 156). Nessa segunda classificação, mais uma divisão é proposta por Peirce, classificando os signos em ícone, índice e símbolo.

"Um ícone é um signo que se refere ao objeto que denota apenas em virtude de seus caracteres próprios (CP 2.247), enquanto o índice "é um signo que se refere ao Objeto que denota em virtude de ser realmente afetado por esse Objeto" (CP 2.248). Já o símbolo "é um signo que se refere ao objeto que denota em virtude de uma lei, normalmente uma associação de ideias gerais que opera no sentido de fazer com que o Símbolo seja interpretado como se referindo àquele objeto" (CP 2.249).

Em relação aos efeitos gerados, terceiro nível analítico do processo de produção de sentido, compreende-se, citando Perez, que "refere-se aos tipos de interpretação que os signos têm o potencial de despertar nos seus usuários, nas mentes que os interpretam.

Para Peirce, no terceiro nível interpretativo, os signos dividem-se em Rema, Dicissigno e Argumento (CP 2.250). Perez nomeia tais signos a partir dos seus efeitos, classificando-os em emocionais, por traduzirem valores como "beleza, status, glamour, aceitação social, poder" (PEREZ, 2004: 157); raionais/funcionais, quando produzem sentido a partir de uma ação ou utilização; lógicos, quando a interpretação depender de "um determinado hábito de consumo" (PEREZ, 2004: 158).

Outra vertente dos estudos de Peirce dedica-se à lógica crítica, “que estuda os tipos de argumentos - abdutivos, indutivos e dedutivos" (SANTAELLA, 2002: 47). A compreensão do raciocínio será relevante para a compreensão da relação do público com a mensagem publicitária na narrativa de entretenimento, bem como acerca do processo de descortinamento da mensagem. 
Semiótica da marca dos produtos Procter \& Gamble no filme "minha mãe é uma peça"

de Pablo Moreno Fernandes Viana

Peirce organiza os raciocínios em três classes, a saber: Dedução, Indução e Retrodução/Abdução. "Dedução é o modo de raciocínio que examina o estado de coisas colocado nas premissas" (CP 2.65); "Indução é o modo de raciocínio que adota uma conclusão como aproximada por resultar ela de um método de inferência que, de modo geral, deve no final conduzir à verdade" (CP 2.67); "Retrodução é a adoção provisória de uma hipótese em virtude de serem passíveis de verificação experimental todas suas possíveis consequências" (CP 2.68).

Peirce afirma que todo raciocínio é diagramático. Ele prossegue explicando que

Construímos um ícone de nosso estado de coisas hipotético e passamos a observá-lo. Esta observação leva-nos a suspeitar que algo é verdadeiro, algo que podemos ou não ser capazes de formular com precisão, e passamos a indagar se é ou não verdadeiro. (CP 2.162)

Assim, a análise do tipo de raciocínio, quando feita a partir da indução, corresponde a verificar a validade de uma teoria aplicada a fenômenos. É o que se faz quando se utiliza a Teoria Geral dos Signos para analisar algum fenômeno. As classes do signo de Peirce são aplicadas aos fenômenos, verificando-se sua aplicação.

Já abdução consiste em formular hipóteses acerca do fenômeno analisado e verificar sua aplicação. Ou seja, sugere-se algo sobre aquilo e verifica se sua validade. A dedução, parte de uma lógica indicial, colocada numa sugestão que é um ponto de partida.

A partir da concepção inicial acerca da tríade marcária e do raciocínio segundo Peirce, daremos início à análise das integrações de produtos em "Minha Mãe é uma peça", verificando o potencial do signo em relação a si mesmo, em nível de primeiridade.

\section{DESCRIÇÃO DAS INSERÇÕES}

A inserção da marca Ariel tem início aos 14 minutos e 52 segundos do filme e vai até 15 minutos e 12 segundos, totalizando aproximadamente 20 segundos de duração. $\mathrm{O}$ nome do produto não é mencionado, mas a cena acontece num supermercado, numa ilha de embalagens de sabões líquidos da marca Ariel 
Semiótica da marca dos produtos Procter \& Gamble no filme "minha mãe é uma peça"

empilhados no ponto de venda. Marcelina, a filha da protagonista, Dona Hermínia, acompanha a mãe em compras no supermercado e esbarra nos produtos, derrubando algumas embalagens. Praticamente no mesmo momento em que a jovem esbarra nos produtos, um funcionário do supermercado aparece para reorganizar a ilha. $\mathrm{O}$ enquadramento em primeiro plano permite a leitura da marca Ariel e também a frase "Remove 3x mais manchas sem desbotar como sabão em pó". As duas personagens aparecem em segundo plano e em terceiro plano aparecem outros produtos expostos nas gôndolas, mas não é possível identificá-los. O produto não chega a ser mencionado no diálogo e a mãe desculpa-se com o funcionário que recolhe os produtos caídos, ao mesmo tempo em que xinga a filha por seu descuido.

A inserção da marca Pantene começa imediatamente após a dos produtos Ariel, também no supermercado, aos 15 minutos e 13 segundos e vai até 15 minutos e 27 segundos. Dona Hermínia e Marcelina caminham pelo supermercado, quando a filha para numa gôndola de produtos Pantene, com uma peça promocional de Ponto de Venda ilustrada com a modelo (e embaixadora da marca) Gisele Bündchen. Marcelina, que está ao lado da mãe, para na gôndola, pega uma embalagem do shampoo Pantene e exclama: “Ai, mãe, eu quero comprar esse shampoo!”. Dona Marcelina responde: "não vai comprar shampoo nenhum. Devolve!”. Marcelina retruca: “Ai, mas eu quero ficar igual à Gisele Bündchen...”, sendo interpelada por Dona Hermínia: "Marcelina, minha filha, você tem outras prioridades, devolve aqui... (e recoloca o shampoo na gôndola)... não vai comprar nada". A garota reclama com a mãe e insiste, quando Dona Hermínia decreta: "Marcelina, não adianta você ter o cabelo da Gisele Bündchen e esse corpo. Você precisa é de dieta, vou te fazer uma sopa, isso sim!" e as duas saem de cena.

À 1 hora, 12 minutos e 10 segundos de filme ocorre uma inserção com as marcas Ariel e Downy. A inserção dura até 1 hora, 12 minutos e 32 segundos e consiste numa simulação de ação de Product Placement comum nos programas de auditório da TV brasileira.

Na história do filme, Dona Hermínia tornou-se apresentadora de um programa de TV e está comentando sobre o cotidiano com os filhos (particularmente, faz uma piada sobre como agredir os filhos sem deixar marca). A inserção tem início com Dona Hermínia olhando para a câmera e falando: "Então gente, você que está em casa e quer dar uma cossa na sujeira, sabe como é que você faz? Aqui ó, vem cá (vira-se 
Semiótica da marca dos produtos Procter \& Gamble no filme "minha mãe é uma peça"

para trás e chama uma das assistentes de palco, que entra segurando nas mãos uma embalagem de Ariel líquido e uma de Downy), vem cá amor. Essa garota, ela é a ralé do programa, é uma dupla infalível que é Ariel líquido e Downy... Tacou Ariel líquido sai a mancha na hora (a câmera enquadra as entrevistadas e retorna para Dona Hermínia). Downy perfuma e tem quatro vezes mais perfume. Então, gente voltando aqui (olha para a assistente)... pode ir garota (dá um risinho)" e termina a inserção.

\section{ANÁLISES SEMIÓTICAS}

No que diz respeito ao signo em si mesmo, em todas as inserções, o local em que as ações se passam é sinsigno.

No caso das duas primeiras inserções, o supermercado surge como espaço particular para a inserção dos produtos na narrativa sem destoar do contexto, uma vez que a mãe cita uma situação com a filha, na qual o local em que acontece é fundamental para a compreensão do que se passa. O cenário torna natural, inclusive, a exibição de outros níveis de expressividade da marca, como bordões publicitários, a garota-propaganda (no caso da Pantene), e peças promocionais.

Na terceira inserção, o local é sinsigno, mas também legissigno. O programa ser interrompido para que a apresentadora anuncie patrocinadores é uma situação recorrente na televisão brasileira, portanto, a inserção no filme não gera estranhamento, pelo contrário, é natural por conta da recorrência na mídia nacional. Ou seja, é sinsigno pela particularidade da situação representada ser reconhecida pelo receptor como a de um programa de TV e legissigno pelo fato de que a interrupção é compreendida naturalmente por qualquer um que tenha o hábito de assistir televisão no Brasil.

Tanto o supermercado, quanto o cenário do programa de televisão aparentam para lugares populares, sendo um supermercado frequentado por uma família de classe média-alta (como a família retratada no filme). Ou seja, a inserção contribui para uma representação do público potencial consumidor do produto. Isso nos leva à análise do signo em relação ao objeto que representa.

No caso da primeira inserção, as duas personagens em cena não comentam o nome do produto, nem sequer fazem menção a ele. A embalagem do produto é exibida, assim como a frase da campanha publicitária veiculada à época da produção 
Semiótica da marca dos produtos Procter \& Gamble no filme "minha mãe é uma peça"

do filme. A representação icônica do produto, por meio da embalagem, sem menção aos seus atributos é reforçada pelo slogan indicial, que afirma as características do produto em relação aos sabões comuns, deixando para o espectador a percepção sobre a mensagem veiculada.

Na segunda inserção, do shampoo Pantene, a relação é mais direta. A filha da protagonista pede à mãe que compre o produto, inserindo a marca e seus atributos como símbolo. No início da inserção, a relação proposta do signo com o objeto é indicial, visto que a garota menciona porque quer comprar o produto, apesar de a modelo aparecer em primeiro plano. Após a negativa da mãe da aquisição, a própria personagem faz a relação do benefício do produto com a garota-propaganda, ao afirmar que se utilizar o shampoo terá o cabelo de Gisele. Tal relação é indicial, mas também simbólica, visto que não é necessário explicar quem é a embaixadora da marca -. A modelo é símbolo de beleza e seu cabelo é apenas um dos seus vários atributos que é cobiçado por outras mulheres. Esse é, possivelmente o motivo que a peça de ponto-de-venda exibida não apresente textos ou sequer faça menção ao nome da modelo, conhecida em todo o mundo.

A terceira inserção, por ser a mais 'publicitária' de todas as exibidas no filme, dessa forma, todo o discurso é icônico, por reproduzir um formato popular da televisão brasileira e é também indicial, ao passo que estabelece referencialidade direta com o objeto representado (e produz humor justamente por isso). A reprodução é também simbólica, porque utiliza símbolos (o clichê das inserções em programas de auditório da TV brasileira) para produzir humor. O reconhecimento do signo em relação ao objeto é, portanto, fundamental. Na mensagem, Dona Hermínia menciona o nome dos produtos e exibe suas embalagens, ao mesmo tempo em que fala das vantagens competitivas de cada um deles.

No que tange aos efeitos gerados, na primeira inserção, apesar de não haver menção ou relação direta do produto com o acontecimento narrado, o efeito pretendido pelo signo junto ao interpretante é de origem funcional, visto que a mensagem exibida em primeiro plano aborda um atributo do produto (a capacidade de remover manchas três vezes mais rápido que um sabão tradicional), um signo dicente, portanto.

$\mathrm{Na}$ segunda inserção, o efeito interpretativo sugerido é remático, visto que o valor sugerido é relacionado ao status. A menina quer usar o shampoo para ter o 
Semiótica da marca dos produtos Procter \& Gamble no filme "minha mãe é uma peça"

cabelo da Gisele Bündchen. Apesar de ser notório o reconhecimento sobre a beleza do cabelo da modelo, o desejo de outras mulheres pelo cabelo semelhante ao dela não é de ordem funcional. O desejo dá-se muito mais pelo glamour e do status relacionado à figura mítica da modelo. A ideia de status é reforçada pela fala da mãe, que desconstrói o desejo da menina pelo shampoo alegando que a garota precisa é de dieta, para estar mais adequada ao padrão de beleza imposto.

A terceira inserção, também apela para a produção de sentido a partir de signos de ordem dicente, apelando aos aspectos funcionais junto ao consumidor. A apresentadora do programa faz breve menção ao nome dos produtos e às suas vantagens competitivas, sem falar de outros assuntos e interpelando diretamente à dona de casa que estaria assistindo ao programa, falando sobre os benefícios diretamente para ela.

\section{CONSIDERAÇÕES FINAIS}

Realizadas as análises, pode-se apresentar algumas considerações sobre as inserções em relação aos valores defendidos pela Procter \& Gamble em cada um dos momentos de "Minha Mãe é uma peça".

Os valores principais da organização, como mencionados, de integridade, liderança, paixão por vencer e confiança fazem-se presentes na primeira inserção, embora o nome do produto não seja mencionado, na frase que expõe o diferencial do produto (que reforça sua qualidade), sem falar que refere-se à missão da organização no que diz respeito a melhorar a vida de consumidores. A preocupação do repositor em recolocar os produtos na ilha assim que caem sinalizam como a marca valoriza o cuidado com seus produtos desde a sua concepção até a organização no ponto de venda.

No caso da marca Ariel, a questão do empoderamento das mulheres por meio da tecnologia, que permitia que elas exercessem outros papeis faz-se presente na primeira inserção e na terceira inserção, por meio da afirmação que Ariel líquido remove mais manchas que um sabão em pó. A questão do empoderamento surge por meio de raciocínio dedutivo. A frase que aparece escrita em primeiro plano na inserção do supermercado e o diferencial afirmado por Dona Hermínia afirmam claramente o benefício do produto, sem deixar espaço para outros questionamentos. 
Semiótica da marca dos produtos Procter \& Gamble no filme "minha mãe é uma peça"

Na segunda inserção, os valores da marca $P \& G$ também fazem-se presentes, mais na garota do que na mãe. Inclusive, é a própria que afirma o desejo de consumir o produto da marca Pantene. O site da Pantene dá destaque à questão dos cuidados com o cabelo no que tange à restauração, mas esse diferencial não é explorado na inserção. No entanto, ao demonstrar o desejo da filha pelo cabelo da embaixadora da marca, a inserção vai de encontro ao trecho do texto de história da marca no site que afirma que "Pantene é sinônimo de performance superior e aliada de Gisele para cuidar da saúde das madeixas mais lindas e inspiradoras do país" (PROCTER \& GAMBLE, 2014).

No caso dessa inserção, o raciocínio é de ordem da abdução, visto que a garota afirma que quer o shampoo para ter o cabelo da Gisele Bündchen e a mãe desconstrói o raciocínio com o argumento de que a garota precisa é de uma dieta, e não de cuidados de cabelo. Nessa fala, particularmente, há conflito entre a fala da mãe e os princípios defendidos pela $\mathrm{P} \& \mathrm{G}$, que afirmam "mostramos respeitos por todos os indivíduos" (PROCTER \& GAMBLE, 2014).

A inserção da marca Downy, segue linha semelhante à dos produtos Ariel. A funcionalidade do produto é destacada, apegando-se a um valor simbólico: a maciez das roupas sentida por meio do toque, como defende o posicionamento de marca apresentado no site da $\mathrm{P} \& \mathrm{G}$. O raciocínio, assim como no caso de Ariel, também é da ordem da dedução.

Como saldo final, observa-se que as três inserções reafirmam o que se propõe no Identity Mix dos produtos da P\&G e, apesar de a combinação de Publicidade e Entretenimento no cinema brasileiro ainda dar os seus primeiros passos rumo a um amadurecimento. A integração, no caso do filme analisado, ainda é bastante rudimentar, mas sua análise contribui para a compreensão de um atual momento do cinema brasileiro e da compreensão das integrações entre publicidade e entretenimento nesse meio.

Como desdobramentos futuros, essa pesquisa pretende aplicar esse modelo de análise a outros filmes nacionais, no intuito de traçar um panorama geral das integrações de produtos em filmes no cinema brasileiro. Pretende, ainda, verificar, em outros meios de comunicação, mais populares no país, como na televisão, por exemplo, qual o cenário atual dessas integrações em novelas, seriados, reality shows e programas de auditório. 
Semiótica da marca dos produtos Procter \& Gamble no filme "minha mãe é uma peça"

\section{REFERÊNCIAS BIBLIOGRÁFICAS}

CHACEL, Marcela Costa da Cunha; BRONSZTEIN, Karla Regina Macena P. Patriota. TRANSMEDIA STORYTELLING: Publicidade, Narrativa e Consumo. IN: TRINDADE, Eneus; PEREZ, Clotilde (Orgs.). I Pró-Pesq - Encontro Nacional de Pesquisadores em Publicidade e Propaganda. São Paulo, 2010: 109-122.

DONATON, Scott. Publicidade + entretenimento: por que estas duas indústrias precisam se unir para garantir a sobrevivência mútua. São Paulo: Cultrix, 2007: 183. ISBN 9788531609879

LUHMANN, Niklas. A realidade dos meios de comunicação. São Paulo: Paulus, 2005. 200p. (Comunicação)

NETO, Celso Figueiredo. Persuasão e Entretenimento: como a publicidadeentretenimento se configura como estratégia comunicativa que resgata a retórica aristotélica. Tese (Doutorado em Comunicação e Semiótica). Pontifícia Universidade Católica de São Paulo. São Paulo, 2008. 236p.

PEREZ, Clotilde; BARBOSA, Ivan Santo (Org.). Hiperpublicidade: volume 1 : fundamentos e interfaces. São Paulo: Thomson, 2008. Xiii: 431. ISBN 9788522103553

PEREZ, Clotilde.Signos da marca: expressividade e sensorialidade. São Paulo: Thomson, 2004: 174. ISBN 8522104425

PEIRCE, Charles S. Semiótica. 4. ed. São Paulo: Perspecticva, 2010. Xii: 337. (Coleção Estudos ; 46) ISBN 9788527301947

PINTO, Júlio. 1, 2, 3 da semiotica. Belo Horizonte: UFMG. 1995. 69p ISBN 8570410980

SANTAELlA, Lúcia. Semiótica aplicada. São Paulo: Pioneira Thomson Learning, Cengage Learning, 2002. Xvii: 186. ISBN 8522102767

SANTOS, Gilmar. Princípios da publicidade. Belo Horizonte: Ed. UFMG, 2005: 229. (Didática, 4)

SÊGA, Christina Maria Pedrazza. Publicidade, Entretenimento e Consumo: Aspectos Interativos. IN: Novos Olhares - vol. 1. N. 2. 2012, São Paulo, SP. 
Semiótica da marca dos produtos Procter \& Gamble no filme "minha mãe é uma peça"

de Pablo Moreno Fernandes Viana

Artigo submetido: 15/05/2014

Artigo aprovado: 10/06/2014 